\title{
Jätevesilietefosforin liukoisuus maassa
}

\author{
Kari Ylivainio ${ }^{1}$ ja Petri Kapuinen ${ }^{2}$ \\ ${ }^{1}$ MTT, Kasvintuotannon tutkimus, 31600 Jokioinen, kari.ylivainio@mtt.fi \\ ${ }^{2}$ MTT, Kasvintuotannon tutkimus, 21500 Piikkiö, petri.kapuinen@mtt.fi
}

\section{Tiivistelmä}

Fosforilannoitteiden kohonneet hinnat ja ympäristötietoisuus ovat lisänneet viljelijöiden kiinnostusta sivutuotteiden sisältämää fosforia kohtaan. Jätevesilietteet ovat merkittävä fosforilähde, mutta niiden käyttöä rajoittavat $\mathrm{mm}$. haitallisten metallien pitoisuutta ja kuormitusta koskevat rajat sekä levityksestä seuraavat viljelyrajoitukset. Fosforilannoitteeksi soveltuvuuteen vaikuttaa myös jätevesilietteiden sisältämän fosforin liukoisuus, johon taas vaikuttaa suuresti fosforin saostuksessa käytetyt kemikaalit. Tässä tutkimuksessa verrattiin erilaisten lietteiden käsittelymenetelmien vaikutusta lietetuotteiden fosforin liukoisuuteen sekä sen muutoksia kalkitsemattomassa ja kalkitussa maassa ajan kuluessa.

Jätevesilietteet olivat peräisin viideltä eri paikkakunnalla toimivalta jätevedenpuhdistamolta (Forssa, Biovakka Oy; Vehmaa, Pori, Kaarina ja Uusikaupunki). Fosforin saostuksessa oli käytetty rauta- ja alumiinipohjaisia kemikaaleja. Lietetuotteiden hygienisointiin käytettiin KemiCond®menetelmää sekä kalkkistabilointia. Lisäksi lietettä mädätettiin (Forssa, Biovakka Oy) ja separoitiin kiinto- ja nestejakeen erottamiseksi (Biovakka Oy).

Lietetuotteiden fosforin liukoisuus määritettiin Hedleyn fraktioinnilla, jossa näytettä uutetaan peräkkäisillä uuttoliuoksilla (vesi, $0,5 \mathrm{M} \mathrm{NaHCO}_{3}, 0,1 \mathrm{M} \mathrm{NaOH}$ ja $1 \mathrm{M} \mathrm{HCl}$, uuttosuhde 1:60). Jätevesilietteiden vaikututa fosforin liukoisuuteen maassa tutkittiin vuoden kestäneellä inkubointikokeella, minkä aikana koemaasta otettiin maanäytteet Hedleyn fraktiointia varten neljän kuukauden väliajoin. Verranteena käytettiin superfosfaattia. Maahan lisätty kokonaisfosforilisä oli $100 \mathrm{mg} \mathrm{kg}^{-1}$ maata.

Jätevesilietteiden kokonaisfosforipitoisuudet kuiva-ainetta kohden olivat noin $2 \%$. Rauta- ja alumiinipohjaisten saostuskemikaalien käytön seurauksena suurin osa fosforista (noin $80 \%$ ) oli sitoutuneena rauta- ja alumiiniyhdisteisiin. Saostuskemikaalien käyttö laski vesiliukoisen fosforipitoisuuden alle $1 \%$ :n lietteiden kokonaisfosforipitoisuudesta. Saostetun lietteen kalkkistabilointi kasvatti happoliukoisen fosforipitoisuuden jopa $87 \%$ :iin kokonaisfosforista, kun taas vesiliukoisen fosforin osuus jäi ainoastaan $0,1 \%$ :iin.

Kalkkistabiloitu jätevesiliete kasvatti koemaan vesiliukoista fosforipitoisuutta $36 \%$ superfosfaatin aikaansaamasta pitoisuuden kasvusta neljän kuukauden inkuboinnin jälkeen, kun se kalkkistabiloimattomalla rauta- ja alumiiniyhdisteillä saostetuilla lietteillä oli enimmillään $12 \%$. Eniten vesiliukoista fosforipitoisuutta kasvatti Biovakan mädätysjäännöksestä separoitu nestefraktio (rejektivesi), jopa $82 \%$ enemmän kuin superfosfaatin aikaansaama lisäys kalkitussa koemaassa. Jätevesilietteet kasvattivat maan labiilia (vesi $+0,5 \mathrm{M} \mathrm{NaHCO}_{3}$ uutot), kasveille käyttökelpoista fosforipitoisuutta vähemmän kalkitussa ( $\mathrm{pH} \mathrm{6,8)} \mathrm{kuin} \mathrm{kalkitsemattomassa} \mathrm{maassa}(\mathrm{pH} \mathrm{5,4).} \mathrm{Inkubointiajan} \mathrm{pidetessä}$ jätevesilietteiden aikaansaama labiili fosforipitoisuus kasvoi suhteessa superfosfaatin vastaavaan.

Saostuskemikaalien käyttö alentaa jätevesilietteiden sisältämän fosforin liukoisuutta merkittävästi ja sitä kautta myös sen käyttökelpoisuutta kasveille. Pidemmällä ajanjaksolla lieteperäisen fosforin liukoisuus maassa kuitenkin kasvoi suhteessa superfosfaattina lisättyyn fosforiin. Jätevesilietefosfori voikin toimia paremmin pitkäkestoisena fosforilannoitteena.

Asiasanat: fosforin käyttökelpoisuus, fosforin liukoisuus, inkubointikoe, jätevesiliete, kalkkistabilointi 


\section{Johdanto}

Fosfori on hupeneva luonnonvara ja nykyisten, helposti louhittavien fosforivarantojen on arvioitu riittävän 50-100 vuodeksi (Cordell ym. 2009). Suurin osa louhitusta fosforista (90 \%) ohjautuu maatalouden käyttöön fosforilannoitteiksi. Fosforivarantojen ehtyminen johtaakin vääjäämättä fosforilannoitteiden hintojen nousuun. Fosforilannoitteiden hinnannousu sekä pyrkimys vähentää fosforin huuhtoutumista vesistöihin ovat lisänneet kiinnostusta fosforia sisältävien sivutuotteiden kierrätykseen. Yksi tällainen maataloudessa heikosti hyväksikäytetty fosforilähde on jätevesilietteet.

Jätevesilietteiden sisältämän fosforin parempi hyödynnettävyys edellyttāä sen sisältämän fosforin liukoisuuden tuntemista. Tässä tutkimuksessa selvitettiin fosforin liukoisuutta erilaisesti käsitellyissä jätevesilietteissä sekä niiden vaikutusta fosforin liukoisuuteen kalkitsemattomassa ja kalkitussa savimaassa.

\section{Aineisto ja menetelmät}

Tutkimuksessa käytetyt yhdyskuntajätevesilietteet olivat peräisin Forssan, Porin, Kaarinan ja Uudenkaupungin jätevedenpuhdistamoilta. Biovakka Oy:ltä (Vehmaa) peräisin oleva liete sisälsi suurimmaksi osaksi sian lietelantaa. Forssan jätevedenpuhdistamolta peräisin oleva liete oli otettu ennen (F1) ja jälkeen (F2) anaerobisen mädätyksen. Jätevesilietteen stabiloinnin vaikutusta fosforin liukoisuuteen selvitettiin Porin ja Kaarinan jätevedenpuhdistamoilta peräisin olevilta lietteillä. Porin jätevedenpuhdistamon liete oli joko sellaisenaan (P1) tai käsitelty KemiCond® menetelmällä (P2). Kaarinan jätevedenpuhdistamon liete oli stabiloitu lisäämällä $30 \mathrm{~kg} \mathrm{CaO} \mathrm{t}^{-1}$ lietettä (K). Uudenkaupungin jätevedenpuhdistamon liete oli kompostoitu (U). Biovakka Oy:n liete oli otettu ennen (V1) ja jälkeen mesofiilisen mädätyksen (V2). Lisäksi mädätysjäännös separoitiin kiinto- (V3) ja nestejakeeseen eli rejektiveteen (V4). Myös kiinto-osa tulkitaan lannoitevalmistelainsäädännössä mädätysjäännökseksi. Lietetuotteet ilmakuivattiin vetokaapissa, poislukien Biovakalta saadut tuotteet, jotka kuivattiin 80 ${ }^{\circ} \mathrm{C}$ :ssa lämpökaapissa. Forssan esikuivattu liete (F1), Porin jätevedenpuhdistamon lietteet (P1 ja P2) sekä Kaarinan kalkkistabiloitu liete (K) kuivattiin muutama päivä lämpökaapissa $\left(60^{\circ} \mathrm{C}\right)$ ennen ilmakuivausta. Kuivauksen jälkeen lietteet jauhettiin huhmareella ja seulottiin $2 \mathrm{~mm}$ seulalla.

Lietetuotteiden ja superfosfaatin sisältämän fosforin liukoisuus määritettiin modifioidulla Hedleyn fraktiointimenetelmällä (Sharpley ja Moyer, 2000). Hedleyn fraktioinnissa näytteitä uutettiin peräkkäisillä uuttoliuoksilla (1:60): kahdesti deionisoidulla vedellä, $0,5 \mathrm{M} \mathrm{NaHCO}_{3}, 0,1 \mathrm{M} \mathrm{NaOH}$ ja 1 M HCl. Uuttoaika oli 16 h lukuun ottamatta ensimmäistä vesiuuttoa, jossa uuttoaika oli $4 \mathrm{~h}$. Uuton jälkeen näytteet sentrifugoitiin ( $3000 \mathrm{~g}, 15 \mathrm{~min})$, ja uuttonesteen epäorgaaninen fosforipitoisuus määritettiin suodatetusta näytteestä $(0,2 \mu \mathrm{m}$ Nucleopori suodatin: Whatman, Maidstone, UK). Kokonaisfosforipitoisuus määritettiin suodattamattomasta uutteesta autoklavoinnin jälkeen $\left(120{ }^{\circ} \mathrm{C}\right.$ :ssa rikkihappo peroksodisulfaattihajoitus) kaikista muista paitsi $1 \mathrm{M} \mathrm{HCl}$ uutteesta. Kokonaisfosforin ja epäorgaanisen fosforin erotuksen katsotaan kuvaavan orgaanista fosforia. Lietetuotteiden alkuainepitoisuudet ( $\mathrm{P}$, $\mathrm{Fe}, \mathrm{Al}, \mathrm{Ca})$ määritettiin ICP-AES:1la (Thermo Jarrel Ash, Franklin, MA) mikroaaltouunihajoituksen jälkeen (kuningasvesi-HF). Lietetuotteiden hiilipitoisuus analysoitiin CN 2000 analysaattorilla (LECO, St. Joseph, MI).

Lietetuotteiden fosforin liukoisuutta kalkitsemattomassa $(\mathrm{pH} 5,4)$ ja kalkitussa $(\mathrm{pH}$ 6,8) savimaassa (savespitoisuus $67 \%$ ) tutkittiin inkubointikokeella. Ennen inkubointikokeen alkua kalkin [10 g $\mathrm{Ca}(\mathrm{OH})_{2} \mathrm{~kg}^{-1}$ maata] annettiin reagoida seulotun $(2 \mathrm{~mm})$ maan kanssa seitsemän viikon ajan ja maan kosteus pidettiin $70 \%$ :ssa vedenpidätyskyvystä. Inkubointikokeessa maata (500 g) muhitettiin edellä mainittujen fosforilähteiden kanssa vuoden ajan. Fosforilähteitä lisättiin maahan siten, että kokonaisfosforilisäys oli $100 \mathrm{mg} \mathrm{kg}^{-1}$ maata. Verranteena käytettiin superfosfaattia (SF). Koemaat kostutettiin $70 \%:$ :iin vedenpidätyskyvystä deionisoidulla vedellä ja koeastiat peitettiin tuorekelmulla, johon tehtiin reikiä ilmanvaihdon mahdollistamiseksi. Koemaiden kosteus tarkistettiin kahden viikon välein punnitsemalla ja haihtunut vesimäärä korvattiin deionisoidulla vedellä. Koeastiat säilytettiin tasalämpöhuoneessa $21^{\circ} \mathrm{C}$ :ssa. Käsittelyistä oli kolme rinnakkaista.

Koeastioista otettiin maanäytteet neljän kuukauden välein. Paria päivää ennen maanäytteiden ottoa koemaat kostutettiin $70 \%$ :iin vedenpidätyskyvystä. Ennen maanäytteen ottoa (50 - $100 \mathrm{~g})$ maa sekoitettiin hyvin. Maanäytteet ilmakuivattiin $\left(35^{\circ} \mathrm{C}\right)$, seulottiin $(2 \mathrm{~mm})$ ja maan $\mathrm{pH}$ määritettiin maavesisuspensiosta $(1: 2,5 \mathrm{v} / \mathrm{v})$. Fosforin liukoisuus määritettiin Hedleyn fraktiointimenetelmällä kuten 
edellä. Koemaiden viljavuusuuttoinen fosforipitoisuus määritettiin happamalla ( $\mathrm{pH} 4,65)$ ammoniumasetaatti uutolla (Vuorinen ja Mäkitie, 1955).

\section{Tulokset ja tulosten tarkastelu}

\section{Fosforin liukoisuus lietetuotteissa}

Lietetuotteiden kokonaisfosforipitoisuudet ilmakuivaa näytettä kohden vaihtelivat 17,2 - 23,9 g $\mathrm{kg}^{-1}$ välillä (Taulukko 1). Lietteiden kuiva-ainepitoisuudet olivat alhaisimmillaan 1,6\% (V4) ja suurimmillaan 75,6\% (V3). Kunnallisten jätevedenpuhdistamolietteiden rautapitoisuudet ovat huomattavasti korkeammalla tasolla kuin Biovakka Oy:ltä peräisin olevissa lietteissä (Taulukko 1). Syynä tähän on sianlannan suuri osuus Biovakka Oy:n lietteissä. Kalkkistabiloinnin seurauksena Kaarinan jätevedenpuhdistamon lietteen kalsiumpitoisuus oli huomattavasti suurempi verrattuna muihin lietteisiin.

Taulukko 1. Inkubointikokeessa käytettyjen fosforilähteiden fosfori (P)-, rauta (Fe)-, alumiini (Al)-, kalsium (Ca)- ja hiilipitoisuudet (C), $\mathrm{g} \mathrm{kg}^{-1}$ ilmakuivaa näytettä.

\begin{tabular}{|l|l|l|l|l|l|}
\hline & $\mathrm{P}$ & $\mathrm{Fe}$ & $\mathrm{Al}$ & $\mathrm{Ca}$ & $\mathrm{C}$ \\
\hline F1, Forssa, ennen anaerobista mädätystä & 21,1 & 94,1 & 13,0 & 19,8 & 342 \\
\hline F2, Forssa, anaerobisen mädätyksen jälkeen & 23,9 & 104,0 & 12,7 & 17,6 & 235 \\
\hline P1, Pori, käsittelemätön liete & 20,9 & 76,8 & 28,3 & 17,7 & 319 \\
\hline P2, Pori, KemiCond® menetelmä & 20,5 & 49,0 & 21,0 & 6,5 & 365 \\
\hline U, Uusikaupunki & 17,2 & 48,1 & 53,5 & 14,1 & 170 \\
\hline K, Kaarina, kalkkistabiloitu liete & 22,7 & 78,2 & 10,5 & 158,0 & 186 \\
\hline V1, Vehmaa, käsittelemätön liete & 17,2 & 8,0 & 18,6 & 18,7 & 287 \\
\hline V2, Vehmaa, mesofiilinen, anaerobinen mädätys & 20,3 & 11,1 & 23,1 & 23,3 & 218 \\
\hline V3, Vehmaa, mädätysjäännöksen kiintojae & 21,2 & 10,1 & 25,9 & 27,2 & 181 \\
\hline V4, Vehmaa, mädätysjäännöksen nestejae (rejektivesi) & 14,0 & 0,6 & 0,3 & 3,2 & 220 \\
\hline SF, superfosfaatti & 89,2 & 2,1 & 1,9 & 202 & - \\
\hline
\end{tabular}

Hedleyn fosforifraktioiden summa oli keskimäärin 98,6 \% totaalianalyysin fosforipitoisuudesta. Heikoiten Hedleyn fraktioinnin uuttoliuokset uuttivat fosforia kalkkistabiloidusta lietteestä ( $83 \%$ totaalista). Suurin osa eli 84,4 - 99,8 \% fosforifraktioiden summasta oli epäorgaanista fosforia. Eniten orgaanista fosforia oli Forssan jätevesilietteissä, 13,6 - 15,6 \%. Tästä pitoisuudesta suurin osa oli 0,1 $\mathrm{M} \mathrm{NaOH}$-uuttuvaa $(13,0-13,3 \%)$.

Jätevesilietteiden sisältämä fosfori oli vaikealiukoisessa muodossa (Kuva 1). Vesiliukoisen, epäorgaanisen fosforin osuus fraktioiden kokonaisfosforipitoisuudesta oli korkeintaan muutama prosentti (KemiCond $\AA, 3,3 \%$ ). Sen sijaan Biovakka Oy:n lietetuotteissa vesiliuokoiset fosforipitoisuudet olivat huomattavasti suuremmat, rejektivedessä jopa $91 \%$ (Kuva 1). Suurempaa vesiliukoista fosforipitoisuutta selittää pienempi, fosforia saostavan raudan ja alumiinin pitoisuudet verrattuna muihin jätevesilietteisiin. Hedleyn fraktioinnin perusteella kalkkistabiloitu jätevesiliete (K) oli lietetuotteista heikkoliukoisin. Happoliukoisen fosforin osuus oli $87 \%$ fraktioiden kokonaissummasta, kun se ilman kalkkistabilointia oli alle $30 \%$ ja suurin osa fosforista oli sitoutuneena $0,1 \mathrm{M} \mathrm{NaOH}$-fraktioon (Kuva 1), jonka katsotaan uuttavan raudan saostamaa fosforia (Hartikainen, 1979). 


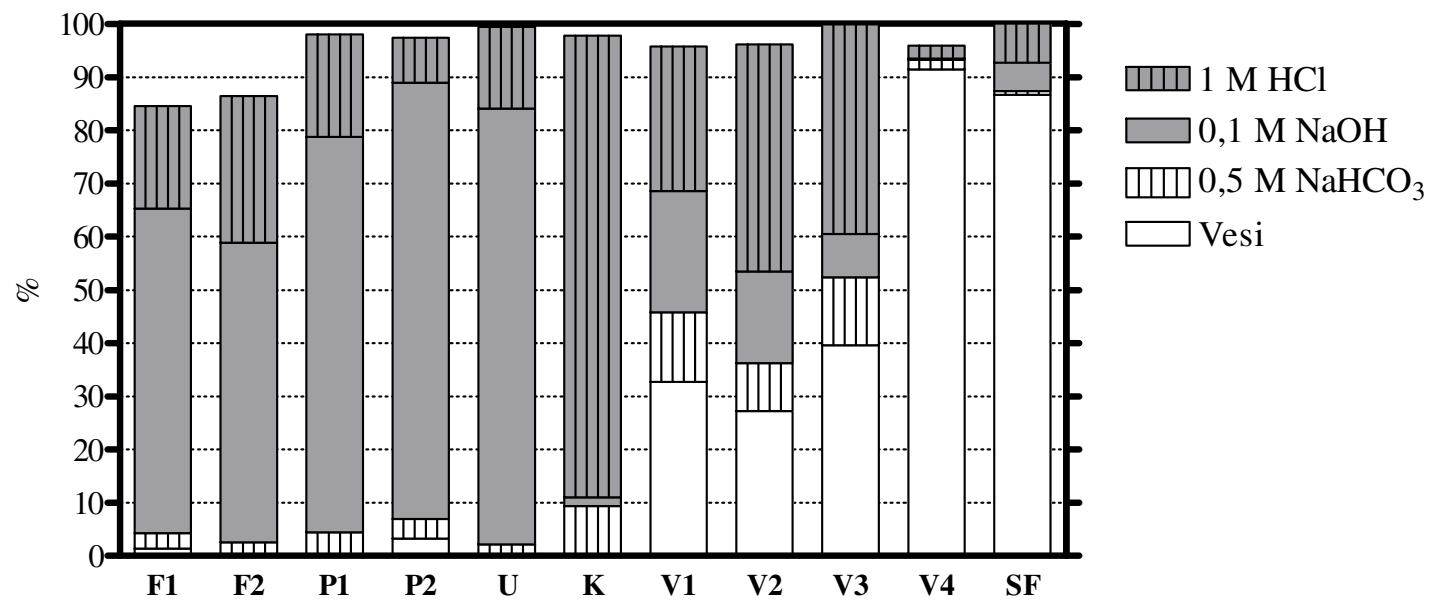

Kuva 1. Fosforilähteiden epäorgaanisen fosforijakeiden osuus Hedleyn fosforifraktioiden summasta.

\section{Inkubointikoe}

Koemaan kalkitseminen kasvatti viljavuusuuttoista fosforipitoisuutta arvosta 1,5 arvoon 2,6 mg $1^{-1}$. Koemaan kalkitseminen kasvatti myös Hedleyn fraktioinnin perusteella määritettyä vesiuuttoista fosforipitoisuutta (2,1 ja 3,6 mg kg-1) ja labiilia fosforipitoisuutta (vesi + 0,5 $\mathrm{M} \mathrm{NaHCO}_{3}$ uuttoinen) arvosta 26,5 arvoon 41,9 $\mathrm{mg} \mathrm{kg}^{-1}$. Merkittävin vaikutus maan kalkitsemisella oli orgaaniseen fosforipitoisuuteen ( $0,1 \mathrm{M} \mathrm{NaOH}$-uuttoinen), joka aleni arvosta 385 arvoon $311 \mathrm{mg} \mathrm{kg}^{-1}$. Kalkitsemisen onkin havaittu kasvattavan orgaanisen fosforin liukoisuutta (Murphy, 2007). Lietetuotteista ainoastaan rejektivesi (V3) ylläpiti vesiliukoista, orgaanista fosforipitoisuutta kontrollikäsittelyä korkeammalla tasolla kalkitsemattomassa maassa kaikkina näytteenottohetkinä ja kalkitussa maassa lukuun ottamatta viimeistä näytteenottoa (12 kk). Muiden orgaanisten fosforifraktioiden pitoisuuksiin lietetuotteilla ei ollut yhtä merkittävää vaikutusta.

Forssan, Porin ja Uudenkaupungin jätevedenpuhdistamoilta peräisin oleva liete ei kasvattanut vesiuuttoista, epäorgaanista fosforipitoisuutta tilastollisesti merkitsevästi inkubointikokeen ensimmäisen kahdeksan kuukauden aikana (Kuva 2), mutta vuoden inkuboinnin jälkeen Forssan ja Porin jätevesilietteet (F1, P1 ja P2) kasvattivat sitä tilastollisesti merkitsevästi kalkitsemattomassa maassa. Jätevesilietteen anaerobinen mädättäminen (F2) laski vesiliukoisen fosforin osuutta jätevesilietteessä, mikä oli havaittavissa myös hieman alhaisempana vesiliukoisena fosforipitoisuutena inkubointikokeessa. Ero ei ollut kuitenkaan tilastollisesti merkitsevä. Happamemmassa maassa KemiCond® menetelmällä käsitelty liete kasvatti vesiliukoista fosforipitoisuutta hieman enemmän kuin käsittelemätön liete, mutta kalkitussa maassa vastaavaa vaikutusta ei havaittu (Kuva 2). Tilastollisesti ero ei ollut merkitsevä kummassakaan maan pH:ssa.

Kalkkistabiloitu liete kasvatti vesiliuokoista fosforipitoisuutta enemmän kuin muut jätevedenpuhdistamoilta peräisin olevat lietteet (Kuva 2) huolimatta siitä, että se sisälsi lähes $90 \%$ happoliukoista fosforia. Kalkkistabiloinnin seurauksena osa raudan ja alumiinin sitomasta fosforista oli mitä ilmeisimmin muuntunut kalsiumin sitomiksi yhdisteiksi ja muuntui vesiliukoiseen muotoon lievästi happamassa maassa. Hedleyn fraktioinnin perusteella lihaluujauhon sisältämä fosfori on liukoisuudeltaan kalkkistabiloidun jätevesilietten veroista. Lihaluujauhon sisältämästä fosforista vain $2 \%$ oli epäorgaanisessa, vesiliukoisessa ja $92 \%$ happoon liukenevassa muodossa (Ylivainio ja Turtola, 2009). Siitä huolimatta lihaluujauho kasvatti vesiliukoisen fosforipitoisuuden happamassa ( $\mathrm{pH} \mathrm{5,4)} \mathrm{savimaas-}$ sa vastaavalle tasolle kuin superfosfaatti, mutta kalkitussa maassa $(\mathrm{pH} \mathrm{6,8)} \mathrm{vastaavaa} \mathrm{vaikutusta} \mathrm{ei}$ havaittu.

Kaikki Biovakka Oy:ltä peräisin olevat lietetuotteet ylläpitivät vesiliukoista fosforipitoisuutta korkeammalla tasolla kuin pelkkää jätevesilietettä sisältävät fosforilähteet (Kuva 2). Rejektivesi (V4) kasvatti fosforin liukoisuutta koemaassa jopa enemmän kuin superfosfaatti. Happamassa koemaassa vesiliukoinen fosforipitoisuus aleni kolmanneksella superfosfaattia saaneessa koemaassa vuoden inkuboinnin aikana, kun se muilla fosforilähteillä pysyi lähes ennallaan (Kuva 2). Syynä voi olla lietteiden 
sisältämä orgaaninen aines, joka pidättäytyessään oksidien pinnoille heikentää fosforin sitoutumista maahan (Iyamuremye \& Dick, 1996).

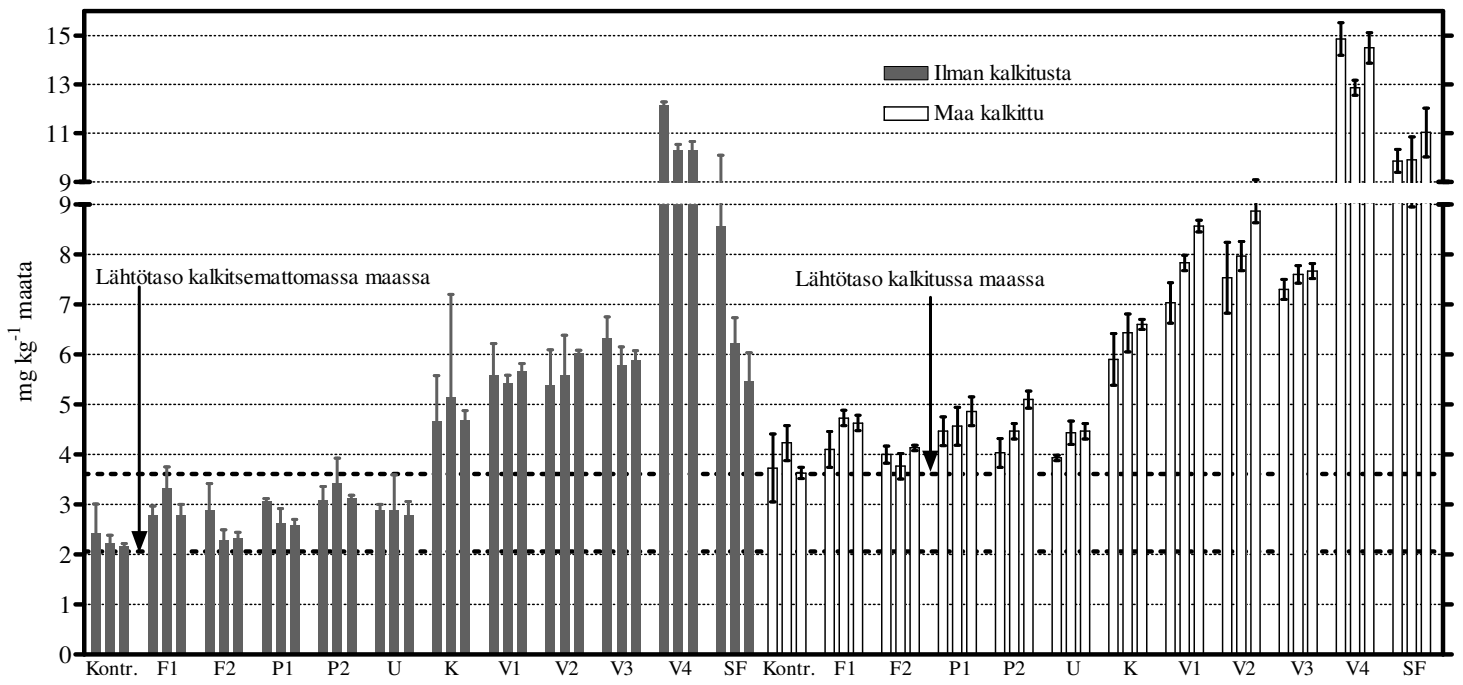

Kuva 2. Vesiliukoinen, epäorgaaninen fosforipitoisuus kalkitsemattomassa ja kalkitussa koemaassa 4, 8 ja 12 kuukauden inkubointikokeen jälkeen.

Jätevesilietteiden aikaansaama vesiliukoinen fosforipitoisuuden kasvu happamemmassa maassa oli ilman kalkkistabilointia enimmillään noin 30 \% väkilannoitteen (SF) vastaavasta kasvusta, kun se kalkkistabiloinnin seurauksena oli jopa $100 \%$ (Kuva 3). Maan kalkitseminen alensi lietteiden sisältämän fosforin liukoisuutta maassa. Useimmat lietetuotteet kasvattivat maan vesiliukoista fosforipitoisuutta suhteessa superfosfaattiin ajan kuluessa (Kuva 3). Vaikutus oli pienempi kalkitussa koemaassa. Rejektiveden (V4) sisältämä fosfori kasvatti maan vesiliukoisen fosforipitoisuuden jopa yli kaksinkertaiseksi superfosfaattiin verrattuna.

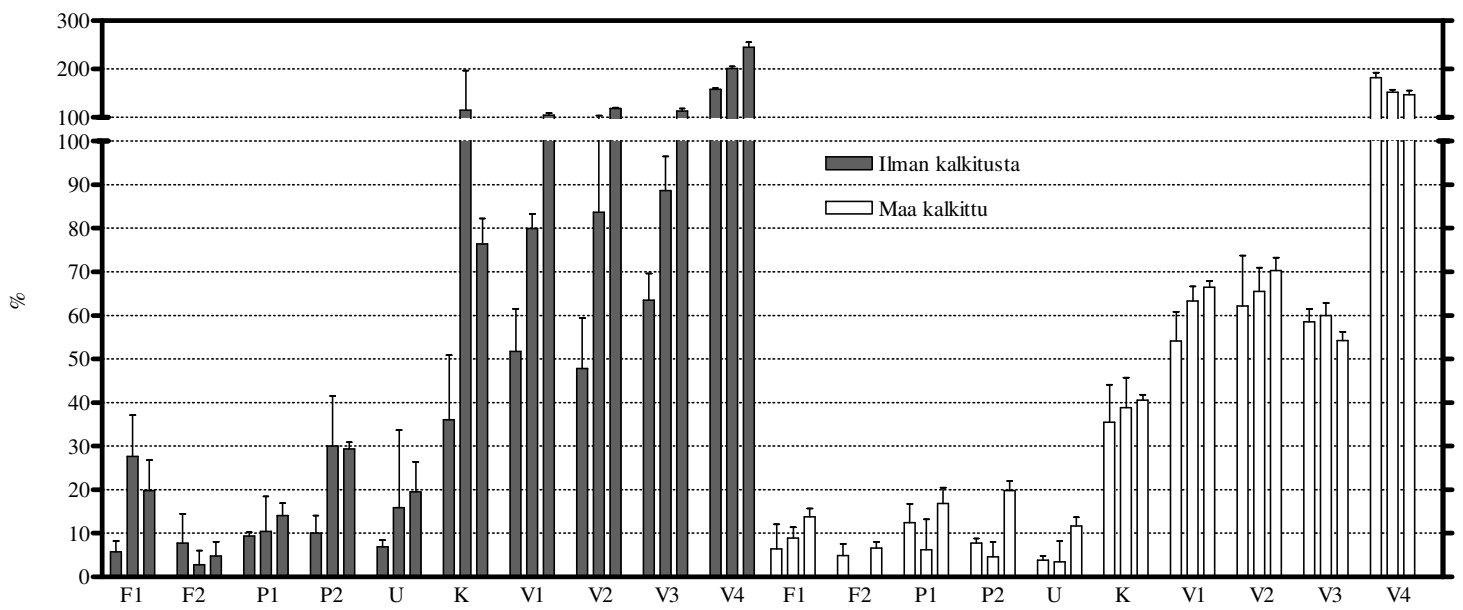

Kuva 3. Lietteiden aikaansaama vesiliukoisen, epäorgaanisen fosforin liukoisuuden muutos kalkitsemattomassa ja kalkitussa koemaassa suhteessa superfosfaatin vastaavaan 4, 8 ja 12 kuukauden inkuboinnin jälkeen.

Vesi- ja 0,5 $\mathrm{M} \mathrm{NaHCO}_{3}$-uuton katsotaan kuvaavan labiilia eli kasveille käyttökelpoista fosforipitoisuutta. Kuten vesiliukoisenkin fosforipitoisuuden kohdalla, myös lietteiden aikaansaama labiili fosforipitoisuus kasvoi ajan kuluessa (Kuva 4). Superfosfaattiin verrattuna jätevesilietteiden (Forssa, Pori, Uusikaupunki) aikaansaama labiili fosforipitoisuus kasvoi inkubointikokeen edetessä ja oli 8 ja 12 kuukauden kohdalla $40 \%$, mikä vastaa nykyisen maatalouden ympäristötukijärjestelmän mukaista 
$40 \%$ käyttökelpoisuutta. Kalkitussa koemaassa vastaava osuus oli $30 \%$ eli korkeammassa maan $\mathrm{pH}$ :ssa lietefosfosforin liukoisuus aleni. Suomessa viljavuusuuttoliuoksena käytetään hapanta ammoniumasetaattiliuosta $(\mathrm{pH} 4,65)$ kun taas Olsenin uuttoliuos $\left(0,5 \mathrm{M} \mathrm{NaHCO}_{3}, \mathrm{pH} 8,5\right)$ soveltuvuu paremmin kalkkipitoisille maille. Tästä johtuen Hedleyn fraktioinnin perusteella määritettyyn labiiliin fosforipitoisuuteen pitää suhtautua varauksella. Fosforin käyttökelpoisuuden mittarina toimivatkin parhaiten kasvatuskokeet. Kesällä 2011 suoritetussa astiakokeessa puhdistamolietefosforin (Forssan jätevedenpuhdistamo, F2) aikaansaaman sadonlisän perusteella laskettu fosforin käyttökelpoisuus oli 4 $\%$ (julkaisematon aineisto). Kokeen kesto oli kuitenkin vain noin kolme kuukautta. Jotta lietteiden sisältämä fosfori voitaisiin paremmin hyödyntää kasvintuotannossa, olisi selvitettävä maan pH:n vaikutus lietefosforin käyttökelpoisuuteen sekä pitkänajan lannoitusvaikutus.

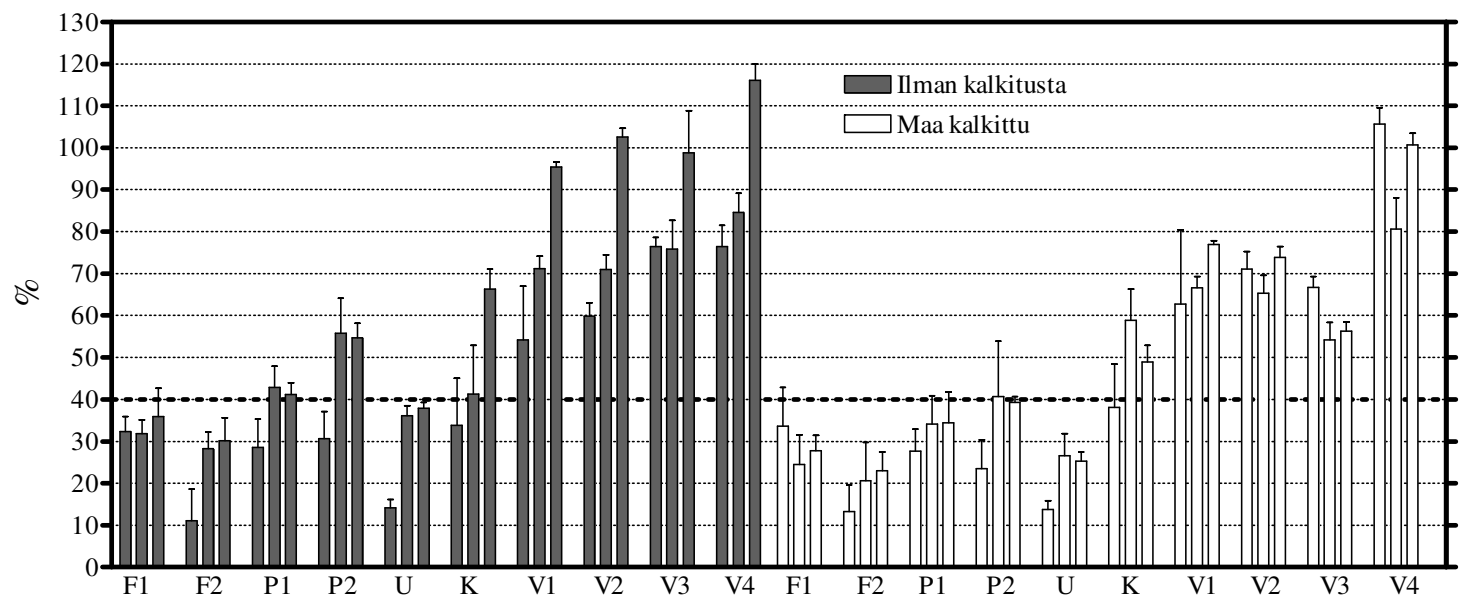

Kuva 4. Lietetuotteiden aikaansaama maan labiilin fosforipitoisuuden muutos suhteessa superfosfaattiin inkubointikokeessa 4, 8 ja 12 kuukauden jälkeen. Katkoviiva kuvaa jätevesilietefosforille asetettua $40 \%$ käyttökelpoisuutta.

Kaikki fosforilähteet kasvattivat $0,1 \mathrm{M} \mathrm{NaOH}$-uuttamaa epäorgaanista fosforipitoisuutta, minkä katsotaan antavan kuvan raudan sitomasta fosforista (Hartikainen, 1979). Se on myös kasveille heikosti käyttökelpoinen fosforilähde. Myös superfosfaatti kasvatti $0,1 \mathrm{M} \mathrm{NaOH}$ uuttamaa epäorgaanista fosforipitoisuutta merkitsevästi ja suurin osa lisätystä fosforista oli sitoutuneena tähän fraktioon. Kalkitsemattomassa maassa keskimäärin 69 ja kalkitussa maassa $54 \%$ lisätystä fosforista oli 0,1 $\mathrm{M} \mathrm{NaOH}$ uuttamassa fraktiossa. Tulos osoittaa kalkituksen heikentävän fosforin sitoutumista maahan ja parantavan siten sen käyttökelpoisuutta kasveille.

Kalkitsemattomassa maassa ainoastaan kalkkistabiloitu liete kasvatti happouuttoista $(1 \mathrm{M} \mathrm{HCl})$ fosforipitoisuutta tilastollisesti merkitsevästi neljän kuukauden inkuboinnin jälkeen. Kahtena viimeisenä (8 ja 12 kk) näytteenottohetkenä ero ei enää ollut merkitsevä, mikä viittaa kalsiumfosfaattien liukenemiseen. Kalkitussa koemaassa kalkkistabiloitu liete sen sijaan oli ainoa fosforilähde joka ylläpiti happoliukoisen fosforipitoisuuden korkeammalla tasolla koko inkubointiperiodin ajan.

\section{Johtopäätökset}

Fosforin saostamiseen käytettävät kemikaalit jätevedenpuhdistuksessa alentavat fosforin liukoisuutta lietteessä ja siten myös lietefosforin käyttökelpoisuutta kasveille. Jätevesilietteen kalkkistabilointi alensi fosforin liukoisuutta edelleen, mutta maan kanssa reagoidessaan kasvatti maan vesiliukoista fosforipitoisuutta enemmän kuin ainoastaan saostuskemikaaleilla käsitellyt lietteet. Kalkkistabiloidun jätevesilietteen sisältämän fosforin liukoisuus aleni maan kalkituksen seurauksena (Maan pH 5,4 ja 6,8). Jätevesilietteiden sisältämän fosforin lannoitevasteista on vain vähän tutkimustietoa, mutta inkubointikokeen tulokset osoittivat, että lietteet ylläpitivät vesiliukoista fosforipitoisuutta happamassa maassa paremmin kuin väkilannoitefosfori. Tulos puoltaakin lietteiden käyttöä pitkäkestoisena fosforilannoitteena. Fosforin käyttökelpoisuuden tarkempi arviointi vaatii kuitenkin kasvatuskokeita. Lisäksi eri kasvien tehokkuus hyväksikäyttää lietteiden sisältämää fosforia saattaa vaihdella. 


\section{Kirjallisuus}

Cordell, D., Drangert, J.-O. \& White, S. 2009. The story of phosphorus: Global food security and food for thought. Global Environmental Change 19: 292-305.

Hartikainen, H. 1979. Phosphorus and its reaction in terrestrial soils and lake sediments. Journal of the Scientific Agricultural Society of Finland 51: 537-624.

Iyamuremye, F. \& Dick, R.P. 1996. Organic amendments and phosphorus sorption by soils. Agronomy Journal 56: 139-185.

Murphy, P.N.C. 2007. Lime and cow slurry application temporarily increases organic phosphorus mobility in soils. European Journal of Soil Science 58: 794-801.

Sharpley, A.N. \& Moyer, B. 2000. Phosphorus forms in manure and compost and their release during simulated rainfall. Journal of Environmental Quality 29: 1462-1469.

Vuorinen, J. \& Mäkitie, O. 1955. The method of soil testing in use in Finland. Agrogeological Publications 63: 1-44.

Ylivainio,K. \& Turtola, E. 2009. Kotieläintalouden ylijäämäfosfori kasvintuotannossa. Teoksessa: Turtola, E. \& Ylivainio, K. (toim.) Suomen kotieläintalouden fosforikierto - säätöpotentiaali maatiloilla ja aluetasolla. Maaja elintarviketalous 138. s. 65-160. 